\title{
Distribution and utilization of vector control strategies in a malarious village of Jabi Tehnan District, north-western Ethiopia
}

\author{
Abebe Animut", Yohannes Negash and Nigatu Kebede
}

\begin{abstract}
Background: Adequate coverage and proper use of long-lasting insecticidal nets (LLINS) and indoor residual spaying (IRS) reduce density of indoor-resting mosquitoes, man-mosquito contact and malaria infection. However, distribution, ownership and usage of the interventions may vary among households in a malarious area, which in turn limits the impact of interventions on the transmission of malaria. A study was undertaken to assess distribution and utilization of LLINs and IRS in a malarious village of north-western Ethiopia.

Methods: A total of 352 randomly selected households in Jiga Yelmdar village, Jabi Tehnan District of north-western Ethiopia were interviewed using a structured questionnaire. The most important questions included distribution and utilization of LLINs/IRS and knowledge by the households of malaria and the interventions.

Results: More than 99\% of the respondents had information about malaria. About 97\% of the households had at least one LLIN and $89.3 \%$ of houses had been treated with IRS within the previous six months. Only $58.2 \%$ of the LLIN-owning households had used the nets the previous night. Not being a malaria transmission season was the main reason cited by $69.7 \%$ of the households for not using their LLINs the previous night. The most preferred malaria control strategy in the village was LLINs (cited by $71.1 \%$ ) followed by IRS (cited by 14.5\%). About 29\% of the households had a history of malaria within the previous six months and the great majority of them (86.3\%) sought treatment at the Jiga Yelmdar Health Post or Jiga Health Centre.

Conclusion: Residents of Jiga Yelmdar village were knowledgeable about malaria and the control strategies of the disease such as LLINs and IRS. Although LLIN use is their most preferred strategy, the compliance rate was low which probably contributed to the $29 \%$ of household-level malaria infection in the village within the previous six months. This indicates the need for improved compliance to LLINs and IRS in the village.
\end{abstract}

\section{Background}

Long-lasting insecticidal nets (LLINs) and indoor residual spaying (IRS) are the vector control strategies that have contributed to the current reduction in the global malaria burden [1,2]. LLINs are used for personal protection against nuisance biting insects, including malaria vectors. They also protect individuals who reside within a few metres of LLIN-using households [3]. IRS saved lives in Europe, Asia and the Americas between the 1940s and the 1980s [2]. It rapidly reduced density and longevity of anopheline mosquitoes and therefore malaria transmission, when properly applied [1,2]. IRS can

\footnotetext{
*Correspondence: animut2004@yahoo.com

Aklilu Lemma Institute of Pathobiology, Addis Ababa University, P O Box 1176, Addis Ababa, Ethiopia
}

also be combined with LLINs in areas where vectors develop resistance to the insecticides used to impregnate net fabrics [2].

Adequate coverage $[4,5]$ and proper use of LLINs and IRS reduce the density of indoor-resting mosquitoes, man-mosquito contact and malaria infection [4,6-9]. The Federal Ministry of Health (FMoH) of Ethiopia has been undertaking a scaled-up distribution of LLINs and IRS as its major malaria control strategies in malarious areas of the country, depending on the local epidemiology of the disease [10]. However, distribution, ownership and usage of the interventions may vary among households and may limit the impact of the interventions on overall malaria transmission in the area. In addition, households need to have knowledge of the strategies and their benefits if 
proper implementation is sought $[2,11,12]$. A study in 17 malarious districts of the country showed distribution and utilization of LLINS to be 97.6 and $81.6 \%$, respectively [13]. In addition, in Arbamich Town and its surrounding district, net coverage and utilization was observed to be 75.1 and $71 \%$, respectively [14]. Other studies also support this trend $[7,15]$. Coverage and utilization of interventions should be assessed and findings communicated to health planners for timely corrective measures and early preparedness. In addition, information on the knowledge and perception by rural households in north-western Ethiopia is limited. This study investigated coverage and utilization of LLINS and IRS and knowledge by inhabitants of these strategies in a malaria-endemic district of northwestern Ethiopia.

\section{Methods}

\section{Study area and design}

Jabi Tehnan is one of the malaria-endemic districts (district refers to Woreda in the Ethiopian context), in the West Gojjam Zone, north-western Ethiopia. The district is bordered on the southeast by Dembecha, on the west by Bure, on the north-west by Sekela, on the north by Quarit and on the east by Dega Damot districts. These bordering districts are malarious.

The district encompasses 41 villages (village refers to Kebele in the Ethiopian context), which are malarious. Among these, Jiga Yelmdar was selected randomly (using lottery method). The village had one health post (Jiga Yelmdar Health Post) and one health centre (Jiga Health Centre). It had 962 households during the study period. LLIN distribution and IRS have been undertaken by the district's health bureau on a regular basis. New LLIN distribution was made in July and August, 2013. In addition, IRS was undertaken in the village in September, 2013 (pers communication, health workers of the village and Jabi Tehnan District). Anticipating the proportion of $50 \%$ of household heads who had heard of both LLINs and IRS, with 95\% confidence interval and a 0.05 absolute precision, a sample size of 384 households was considered in the study.

\section{Data collection}

The 384 household samples were randomly distributed to a total 962 households in the village, first by interviewing a household head in the northern extreme of the village and then by interviewing the next $(962 / 384)^{\text {th }}$ or third household to the southern direction. In case of absence or refusal by the selected household, the next household was considered in the sample. Data were collected in January 2014 using a pre-tested questionnaire developed in English and then translated into the local language (Amharic). The household head or the next elder of each selected household was interviewed. The major variables included in the questionnaire were socio-economic characteristics of households, knowledge of households about malaria interventions, availability of LLINs in households, number of nets used in households, condition of nets, net utilization, history of IRS, history of wall re-plastering and use of LLINs and IRS. Net condition was further divided into good (clean and having no hole), fair (not clean and having no hole), poor (having at least one hole of about $2 \mathrm{~cm}$ in diameter) and still in the package.

\section{Data analysis}

Data were entered and analysed using PASW 18.0 Statistics Version 18 (SPSS Inc, Chicago, IL, USA). The frequency of respondents against the target variable was determined. Association of the variables with the history of malaria infection within the previous six months was analysed using logistic regression.

\section{Ethical issues}

The study was reviewed and approved by the Institutional Review Board of the Aklilu Lemma Institute of Pathobiology, Addis Ababa University. Permission to undertake the study was obtained from West Gojjam Zone and Jabi Tehnan district health bureaus. Informed verbal consent was obtained from all the respondents of the selected study households after the study was explained to them in the local language.

\section{Results}

The socio-demographic characteristic of the surveyed households is presented in Table 1. A total of 352 households were visited and female respondents (226; 64.2\%) were 1.8 times higher than the males (126: 35.8\%). The mean age of the respondents was 36.4 years old ranging from 18 to 80 years. The highest proportion of respondents were illiterate $(47.7 \%)$ followed by able to read and write $(22.2 \%)$, primary school complete $(16.2 \%)$, secondary school (8.2\%) and high school or higher (5.7\%). The great majority of the respondents were farmers $(93.8 \%)$. About $53 \%$ of them did not own any type of media while $46.3 \%$ had radio. The average household size of the village was 4.81 persons.

More than 99\% $(n=350)$ of the respondents had information about malaria and the most frequent information source cited was health workers $(83.2 \%)$ (Table 2). The majority (89.5\%) of respondents reported that they use LLINs to prevent malaria. Almost all (98.9\%) of the respondents had heard about LLINs and most (96.9\%) of them owned at least one LLIN. The households that owned one, two, three, and four or higher LLINs were 136 (39.9\%), 182 (53.4\%), 18 (5.3\%), and $5(1.5 \%)$, respectively.

About 93\% (328/352) of the respondents perceived that LLINs are used to prevent malaria (Table 3). While 6.3\% $(\mathrm{n}=22), 0.3 \%(\mathrm{n}=1)$ and $0.3 \%(\mathrm{n}=1)$ cited that LLINs are 
Table 1 Socio-demographic characteristics of households in Jiga Yelmdar village, Jabi Tehnan District, north-western Ethiopia, January 2014

\begin{tabular}{|c|c|c|}
\hline Characteristic & Category & Number (\%) \\
\hline \multicolumn{3}{|l|}{ Sex of respondents $(n=352)$} \\
\hline & Male & $126(35.8)$ \\
\hline & Female & $226(64.2)$ \\
\hline \multirow{5}{*}{$\begin{array}{l}\text { Educational status of } \\
\text { respondents }(n=352)\end{array}$} & Illiterate & $168(47.7)$ \\
\hline & Read and write & $78(22.2)$ \\
\hline & Primary school & $57(16.2)$ \\
\hline & Secondary school & $29(8.2)$ \\
\hline & High school or higher & $20(5.7)$ \\
\hline \multirow[t]{4}{*}{ Household occupation ( $n=352$ ) } & Farmer & $330(93.8)$ \\
\hline & Merchant & $8(2.3)$ \\
\hline & Government employee & $2(0.6)$ \\
\hline & Other & $12(3.4)$ \\
\hline \multirow{4}{*}{$\begin{array}{l}\text { Media ownership of } \\
\text { households }(n=352)\end{array}$} & Radio & $163(46.3)$ \\
\hline & Television & $1(0.3)$ \\
\hline & Newspaper & $2(0.6)$ \\
\hline & No & $186(52.8)$ \\
\hline \multirow[t]{9}{*}{ Household size $(n=352)$} & 1 & $6(1.7)$ \\
\hline & 2 & $26(7.4)$ \\
\hline & 3 & $65(18.5)$ \\
\hline & 4 & $60(17.0)$ \\
\hline & 5 & $73(20.7)$ \\
\hline & 6 & $55(15.6)$ \\
\hline & 7 & $35(9.9)$ \\
\hline & 8 & $28(8.0)$ \\
\hline & $\geq 9$ & $4(1.2)$ \\
\hline
\end{tabular}

used to prevent mosquitoes, insects and rodents, respectively. About $81 \%(276 / 341)$ of the respondents reported current LLIN use in their households of whom $58.2 \%(198 / 340)$ had slept under an LLIN the previous night. LLIN use by all the family was cited most (57.6\%; $197 / 342$ ) followed by use by father and mother (17.8\%; $61 / 342)$ and use by children and mother (10.2; 35/342). The most cited reason for not sleeping under the available LLIN was that it was not the malaria season $(69.7 \%$; 99/142) followed by others $(29.6 \%$; $42 / 142)$. Most of the LLINs surveyed $(86.5 \%, 204 / 342)$ were in a good condition, while the remainder were poor $(7.6 \% ; 26 / 342)$, fair $(4.7 \% ; 16 / 342)$ and unused $(1.2 \% ; 4 / 342)$. Most $(96.3 \%)$ of the household respondents have been using LLINs for over three years.

Almost all (99.4\%; 350/352) of the respondents have heard about IRS of which the majority (63.4\%; 223/352) did not know the insecticide type employed (Table 4). A high proportion $(67 \% ; 236 / 252)$ of the total respondents perceived that IRS is used to kill mosquitoes. About
Table 2 Knowledge by households of malaria and long-lasting insecticide nets in Jiga Yelmdar village, Jabi Tehnan District, north-western Ethiopia, January 2014

\begin{tabular}{|c|c|c|}
\hline Characteristic & Category & Number (\%) \\
\hline \multirow[t]{2}{*}{ Heard about malaria $(n=352)$} & Yes & $350(99.4)$ \\
\hline & No & $2(0.6)$ \\
\hline \multirow{4}{*}{$\begin{array}{l}\text { Information source about } \\
\text { malaria }(n=351)\end{array}$} & Health worker & $292(83.2)$ \\
\hline & Mass media & $21(6.0)$ \\
\hline & Friend & $23(6.6)$ \\
\hline & Other & $15(4.3)$ \\
\hline \multirow{7}{*}{$\begin{array}{l}\text { Method used to prevent } \\
\text { malaria }(n=352)\end{array}$} & LLINs & $315(89.5)$ \\
\hline & IRS & $11(3.1)$ \\
\hline & Aerosol spray & $1(0.3)$ \\
\hline & Anti-malarial tablet & $10(2.8)$ \\
\hline & Clean surroundings & $10(2.8)$ \\
\hline & Habitat management & $2(0.6)$ \\
\hline & Other & $3(0.9)$ \\
\hline \multirow[t]{2}{*}{ Heard about LLINs $(n=352)$} & Yes & $348(98.9)$ \\
\hline & No & $4(1.1)$ \\
\hline \multirow[t]{2}{*}{ Have LLINs $(n=352)$} & Yes & $341(96.9)$ \\
\hline & No & $11(3.1)$ \\
\hline \multirow{4}{*}{$\begin{array}{l}\text { Number of LLINs per } \\
\text { household }(n=341)\end{array}$} & 1 & $136(39.9)$ \\
\hline & 2 & $182(53.4)$ \\
\hline & 3 & $18(5.3)$ \\
\hline & $\geq 4$ & $5(1.5)$ \\
\hline
\end{tabular}

89.3\% (275/308) of the houses had been treated with IRS within the previous six months and most of them had not been plastered since the last treatment with insecticide.

The most preferred malaria prevention strategy in Jiga Yelmdar was LLINs (74.1\%; 261/352) followed by IRS (14.5\%; 51/352), larval source management (6.3\%; 22/352) and case treatment $(2.6 \%$; 9/352) (Table 5). About 29\% $(n=102)$ of the respondents perceived a history of malaria infection in their households within the previous six months. The majority of infected household members $(86.3 \%$; 88/102) sought treatment in health posts/ centres followed by the cases who bought drugs from drug stores (6.9\%; 7/102).

\section{Discussion}

Almost all of the household respondents had information about malaria, LLINs and IRS and they cited health workers as their main source of information. The village health extension workers undertake a regular house-to-house education on disease control and prevention methods, including malaria. They diagnose febrile patients for malaria clinically and using rapid diagnosis test kits, and treat positive cases following national diagnosis and treatment guideline 
Table 3 Households' knowledge and utilization of long-lasting insecticide nets by households in Jiga Yelmdar village, Jabi Tehnan District, north-western Ethiopia, January 2014

\begin{tabular}{|c|c|c|}
\hline Characteristic & Category & Number (\%) \\
\hline \multirow[t]{4}{*}{ Use of LLINs $(n=352)$} & Prevent malaria & $328(93.2)$ \\
\hline & Kill/prevent mosquito & $22(6.3)$ \\
\hline & Kill/prevent insects & $1(0.3)$ \\
\hline & Kill/prevent rodent & $1(0.3)$ \\
\hline \multirow[t]{2}{*}{ Current LLINs used $(n=341)$} & Yes & $276(80.9)$ \\
\hline & No & $65(19.1)$ \\
\hline \multirow{2}{*}{$\begin{array}{l}\text { Previous night LLINs } \\
\text { used }(n=340)\end{array}$} & Yes & $198(58.2)$ \\
\hline & No & $142(41.8)$ \\
\hline \multirow{3}{*}{$\begin{array}{l}\text { Reason for not using } \\
\text { LLINs }(n=142)\end{array}$} & LLINs are toxic & $1(0.7)$ \\
\hline & Not malaria season & $99(69.7)$ \\
\hline & Other & $42(29.6)$ \\
\hline \multirow[t]{6}{*}{ Who uses LLINs $(n=342)$} & Children & $16(4.7)$ \\
\hline & Mother & $13(3.8)$ \\
\hline & Father & $20(5.8)$ \\
\hline & Father and mother & $61(17.8)$ \\
\hline & Children and mother & $35(10.2)$ \\
\hline & Whole family & $197(57.6)$ \\
\hline \multirow{2}{*}{$\begin{array}{l}\text { Frequency of LLIN } \\
\text { use }(n=342)\end{array}$} & Daily & $204(59.6)$ \\
\hline & Occasionally & $138(40.4$ \\
\hline \multirow[t]{4}{*}{ Condition of LLINs $(n=342)$} & Good & $296(86.5)$ \\
\hline & Fair & $16(4.7)$ \\
\hline & Poor & $26(7.6)$ \\
\hline & Unused (still in package) & $4(1.2)$ \\
\hline \multirow{4}{*}{$\begin{array}{l}\text { Period since LLIN } \\
\text { used }(n=348)\end{array}$} & $<1$ month & $1(0.3)$ \\
\hline & Months ago & $8(2.3)$ \\
\hline & 1-3 years & $4(1.1)$ \\
\hline & $>3$ years & $335(96.3)$ \\
\hline
\end{tabular}

[10]. Diagnosis and treatment of malaria cases is carried out free of charge at the Jiga Yelmdar Health Post. The house-to-house education and the free treatment of cases at the health post might have contributed to increased awareness and treatment-seeking behaviour of households, respectively. This is central for effective implementation of LLINs and IRS in rural malarious areas.

A great majority of the respondents indicated that LLINs prevent malaria. LLINs can reduce malaria transmission especially among children in endemic areas aged under five years $[3,9,12,16]$. This results from the killing, repellency and physical protective effects of the LLINs against mosquitoes $[3,17]$. The mosquito-killing effect of LLINs reduces the age, human contact and sporozoite rate of anophelines. This reduces malaria infection risk
Table 4 Coverage and households' perception of indoor residual spraying in Jiga Yelmdar village, Jabi Tehnan District, north-western Ethiopia, January 2014

\begin{tabular}{|c|c|c|}
\hline Characteristic & Category & Number (\%) \\
\hline \multirow[t]{2}{*}{ Heard about IRS $(n=352)$} & Yes & $350(99.4)$ \\
\hline & No & $2(0.6)$ \\
\hline \multirow{5}{*}{$\begin{array}{l}\text { Insecticide employed for } \\
\text { IRS }(n=352)\end{array}$} & DDT & $125(35.5)$ \\
\hline & Malathion & $1(0.3)$ \\
\hline & Deltamethrin & $1(0.3)$ \\
\hline & Other & $2(0.6)$ \\
\hline & Do not know & $223(63.4)$ \\
\hline \multirow{4}{*}{$\begin{array}{l}\text { Part of the house for } \\
\text { IRS }(n=352)\end{array}$} & Surface of inner wall & $338(96.0)$ \\
\hline & Inner surface of the roof & $4(1.1)$ \\
\hline & All parts & $8(8)$ \\
\hline & Do not know & $2(0.6)$ \\
\hline \multirow[t]{5}{*}{ Use of IRS ( $n=352)$} & To kill mosquitoes & $236(67.0)$ \\
\hline & To kill other domestic insects & $38(10.8)$ \\
\hline & To kill rodents & $1(0.3)$ \\
\hline & To control malaria & $75(21.3)$ \\
\hline & Do not know & $2(0.6)$ \\
\hline \multirow{2}{*}{$\begin{array}{l}\text { House treated by IRS } \\
\text { within past } 12 \text { months }\end{array}$} & Yes & $308(87.5)$ \\
\hline & No & $44(12.5)$ \\
\hline \multirow{2}{*}{$\begin{array}{l}\text { When was the last } \\
\text { IRS }(n=308)\end{array}$} & $>3$ months & $275(89.3)$ \\
\hline & $>6$ months & $34(10.7)$ \\
\hline \multirow[t]{5}{*}{ Frequency of IRS $(n=322)$} & Once per year & $210(65.2)$ \\
\hline & After every six months & $105(32.6)$ \\
\hline & After every three months & $4(1.2)$ \\
\hline & Other & $1(0.3)$ \\
\hline & Do not know & $2(0.6)$ \\
\hline \multirow[t]{4}{*}{ Time of IRS } & In the morning (06:00-12:00) & $91(28.3)$ \\
\hline & At mid day (12:00-13:00) & $114(35.4)$ \\
\hline & Afternoon (13:00-18:00) & $104(32.3)$ \\
\hline & Any time (06:00am-18:00) & $13(4.0)$ \\
\hline \multirow{2}{*}{$\begin{array}{l}\text { Wall plastered since } \\
\text { last IRS }(n=316)\end{array}$} & Yes & $29(9.4)$ \\
\hline & No & $279(90.6)$ \\
\hline
\end{tabular}

among nearby households having no LLINs and IRS [4]. The nets also serve as physical barriers against nuisance biting mosquitoes and insects, irrespective of resistance [3]. Deltamethrin-treated LLINs were observed to have a $60 \%$ malaria preventive effect in an area of highly resistant vectors to the insecticide [9].

In the village, $56.9 \%(n=198)$ of the households owning LLINs and 58.2\% $(\mathrm{n}=198)$ of households reporting current net use perceived use of the nets the previous night. This compliance rate is lower compared with the report from Oromia and Amhara Regions (65\%) [18], the Southern Nations, Nationalities and People's Region (SNNPR) 
Table 5 Reported malaria infection among households within the previous six months and preferred control/ treatment method, in Jiga Yelmdar village, Jabi Tehnan District, north-western Ethiopia, January 2014

\begin{tabular}{lll}
\hline Characteristic & Category & Number (\%) \\
\hline $\begin{array}{l}\text { Preferred malaria prevention } \\
\text { method for the household } \\
(\mathrm{n}=352)\end{array}$ & LLINs & $261(74.1)$ \\
& IRS & $51(14.5)$ \\
& Case treatment & $9(2.6)$ \\
& Larval source management & $22(6.3)$ \\
& Do not know & $9(2.6)$ \\
Malaria infection history in & Yes & $102(29.0)$ \\
household within previous & No & $250(71.0)$ \\
6 months ( $\mathrm{n}=352)$ & & $88(86.3)$ \\
Treatment sought $(\mathrm{n}=102)$ & Health post/centre & $1(1.0)$ \\
& Hospital & $3(2.9)$ \\
& Traditional healer(s) & $7(6.9)$ \\
& Drug store (pharmacy) & $3(2.9)$ \\
\hline
\end{tabular}

(60.6\%) [15] and the 17 malarious districts (81.6\%) [13] of the country. In this cross-sectional study, which was undertaken during a dry season, the most frequently cited reason for not sleeping under an LLIN the previous night (by $69.7 \%$ of the 142 non-compliants) was that it was not a malaria season. This is different from the study in the SNNPR where the main reason mentioned was that nets were too torn [15]. Although the households in Jiga Yelmdar village could experience a lower density of night-biting mosquitoes and possibly lower number of malaria cases during the study period (which was dry) compared with the wet season, this could contribute to a sustained transmission of the disease in the area. The Jiga Yelmdar Health Post reports and entomological collections undertaken in the village revealed occurrence of malaria transmission during the study season (AA, unpublished data).

A high proportion of the respondents (67\%; 236/252) perceived that IRS is used to kill mosquitoes. This indicates that the residents are knowledgeable about the use of IRS. This proportion is higher than that reported from Uganda (48.6\%) [8] although the areas are different. However, more than half of the respondents did not know name of the chemical used for the IRS. This indicates the need to inform inhabitants about the nature of the chemicals being used for IRS, including names, uses and possible side-effects on animals and humans.

Despite the scaled-up coverage of LLINs and IRS in the Jiga Yehmdar village, a high proportion of respondents (29\%) had had malaria infection within the previous six months. This could result from the low level of compliance to LLINs and possibly from resistance of the vectors to the insecticides impregnated in the nets (deltamethrin, perimethrin) and also to chemicals used for IRS (dichlorodiphenyltrichloroethane, malathion) [19-21]. Improved compliance to LLINs can bring a significant reduction in malaria infection risk as the nets provide physical protection even in the presence of insecticide resistance [9]. However, the status of behavioural resistance of the vectors to the LLINs and IRS that are being used in the area, the biting behaviour of vectors before bedtime and their possible outdoor-feeding behaviour remains to be described in the area. This is because the use of LLINs/IRS may force vectors to change their endophilic and endophagic behaviour into exophilic and exophagic [22] and also their biting hours from the period during human sleeping to before bed time $[17,23]$.

\section{Conclusion}

Residents of Jiga Yelmdar village, Jabi Tehnan District, north-western Ethiopia were aware of malaria and the currently employed control strategies, LLINs and IRS, against the disease. Although LLINs were distributed to almost all households and was the most preferred malaria control strategy in the village, the compliance rate (58.2\%) was low which probably contributed to the $29 \%$ household-level reported malaria infection. This study indicates the importance of describing seasonal dynamics and behaviour of local vectors. In addition, compliance of households to malaria interventions (LLINs and IRS) needs to be improved through education and regular supervision.

\section{Competing interests}

The authors declare that they have no competing interests.

\section{Authors' contributions}

AA designed the study, collected data in the field, carried out the data analysis and wrote the manuscript. YN participated in the data collection and interpretation of the results. NK participated in the data analysis and manuscript edition. All authors have read and approved the final manuscript.

\section{Acknowledgements}

This study obtained financial support from the Addis Ababa University Office of the Vice President for Research and Technology through the Thematic Research Program, studies towards Integrated Prevention and Control of Malaria and Other Parasitic Diseases in Ethiopia. The Aklilu Lemma Institute of Pathobiology, Addis Ababa University is duly acknowledged for providing field vehicle used during the data collection. We thank Ato Nega Nigussie for his technical support during data collection.

Received: 15 July 2014 Accepted: 3 September 2014

Published: 10 September 2014

\section{References}

1. WHO: Larval source managment: a supplementary measure for malaria vector control, an operational manual. Geneva: World Health Organization; 2013. www.who.int/malaria/publications/atoz/9789241505604/en/.

2. WHO: Indoor Residual Spraying: an operational manual for indoor residual spraying (IRS) for malaria transmission control and elimination. Geneva: World Health Organization; 2013. apps.who.int/iris/bitstream/10665/80126/1/ 9789241505123_eng.pdf?ua=1.

3. Hawley WA, Phillips-Howard PA, ter Kuile FO, Terlouw DJ, Vulule JM, Ombok M, Nahlen BL, Gimnig JE, Kariuki SK, Kolczak MS, Hightower AW: Community-wide 
effects of permethrin-treated bed nets on child mortality and malaria morbidity in western Kenya. Am J Trop Med Hyg 2003, 68:121-127.

4. Killeen GF, Smith TA, Ferguson HM, Mshinda H, Abdulla S, Lengeler C, Kachur SP: Preventing childhood malaria in Africa by protecting adults from mosquitoes with insecticide-treated nets. PLoS Med 2007, 4:e229.

5. Hawley WA, ter Kuile FO, Steketee RS, Nahlen BL, Terlouw DJ, Gimnig JE, Shi YP, Vulule JM, Alaii JA, Hightower AW, Kolczak MS, Kariuki SK, Phillips-Howard PA: Implications of the western Kenya permethrin-treated bed net study for policy, program implementation, and future research. Am J Trop Med Hyg 2003, 68:168-173.

6. Tami A, Mubyazi G, Talbert A, Mshinda H, Duchon S, Lengeler C: Evaluation of Olyset insecticide-treated nets distributed seven years previously in Tanzania. Malar J 2004, 3:19.

7. Fettene $M$, Balkew M, Gimblet C: Utilization, retention and bio-efficacy studies of PermaNet in selected villages in Buie and Fentalie districts of Ethiopia. Malar J 2009, 8:114

8. Ediau M, Babirye JN, Tumwesigye NM, Matovu JK, Machingaidze S, Okui O, Wanyenze RK, Waiswa P: Community knowledge and perceptions about indoor residual spraying for malaria prevention in Soroti district, Uganda: a cross-sectional study. Malar J 2013, 12:170.

9. Tokponnon FT, Ogouyemi AH, Sissinto Y, Sovi A, Gnanguenon V, Cornelie S, Adeothy AA, Osse R, Wakpo A, Gbenou D, Oke M, Kinde-Gazard D, Kleinschmidt I, Akogbeto MC, Massougbodji A: Impact of long-lasting, insecticidal nets on anaemia and prevalence of Plasmodium falciparum among children under five years in areas with highly resistant malaria vectors. Malar J 2014, 13:76

10. Federal Democratic Ethiopia MoH: National Malaria Guidelines, Third Ediciton, Addis Ababa. http.//unw.moh.gov.et/documents/26765/28899/National+Malaria+Guidelines/ 893d23fo-3c61-4777-a5e-45ea92df055ajssessionid=39AA3CBCB1 A6D3DD446732F328 A59D93?version=1.0.

11. Atieli HE, Zhou G, Afrane Y, Lee MC, Mwanzo I, Githeko AK, Yan G: Insecticide-treated net (ITN) ownership, usage, and malaria transmission in the highlands of western Kenya. Parasit Vectors 2011, 4:113.

12. Lengeler C, Armstrong-Schellenberg J, D'Alessandro U, Binka F, Cattani J: Relative versus absolute risk of dying reduction after using insecticide-treated nets for malaria control in Africa. Trop Med Int Health 1998, 3:286-290.

13. Animut AG-MT, Medhin G, Balkew M, Bashaye S, Seyoum A: Assessment of distribution, knowledge and utiliztion of insecticide treated nets in selected malaria prone areas of Ethiopia. Ethiop J Health Dev 2008, 22:268-274.

14. Astatkie A, Feleke A: Utilization of insecticide treated nets in Arbaminch Town and the malarious villages of Arbaminch Zuria District, Southern Ethiopia. Ethiop J Health Dev 2009, 24:15-24.

15. Batisso E, Habte T, Tesfaye G, Getachew D, Tekalegne A, Kilian A, Mpeka B, Lynch C: A stitch in time: a cross-sectional survey looking at long lasting insecticide-treated bed net ownership, utilization and attrition in SNNPR, Ethiopia. Malar J 2012, 11:183.

16. Alonso PL, Lindsay SW, Armstrong JR, Conteh M, Hill AG, David PH, Fegan G, de Francisco A, Hall AJ, Shenton FC, Cham K, Greenwood BM: The effect of insecticide-treated bed nets on mortality of Gambian children. Lancet 1991, 337:1499-1502.

17. Mathenge EM, Gimnig JE, Kolczak M, Ombok M, Irungu LW, Hawley WA: Effect of permethrin-impregnated nets on exiting behavior, blood feeding success, and time of feeding of malaria mosquitoes (Diptera: Culicidae) in western Kenya. J Med Entomol 2001, 38:531-536.

18. Baume CA, Reithinger R, Woldehanna S: Factors associated with use and non-use of mosquito nets owned in Oromia and Amhara regional states, Ethiopia. Malar J 2009, 8:264

19. Balkew M, Elhassen I, Ibrahim M, Gebre-Michael T, Engers H: Very high DDT-resistant population of Anopheles pharoensis Theobald (Diptera: Culicidae) from Gorgora, northern Ethiopia. Parasite 2006, 13:327-329.

20. Balkew M, Ibrahim M, Koekemoer LL, Brooke BD, Engers H, Aseffa A, Gebre-Michael T, Elhassen I: Insecticide resistance in Anopheles arabiensis (Diptera: Culicidae) from villages in Central, northern and south west Ethiopia and detection of kdr mutation. Parasit Vectors 2010, 3:40.

21. Yewhalaw D, Wassie F, Steurbaut W, Spanoghe P, Van Bortel W, Denis L, Tessema DA, Getachew Y, Coosemans M, Duchateau L, Speybroeck N: Multiple insecticide resistance: an impediment to insecticide-based malaria vector control program. PLoS One 2011, 6:e16066.
22. Sougoufara S, Diedhiou SM, Doucoure S, Diagne N, Sembene PM, Harry M, Trape JF, Sokhna C, Ndiath MO: Biting by Anopheles funestus in broad daylight after use of long-lasting insecticidal nets: a new challenge to malaria elimination. Malar J 2014, 13:125.

23. Yohannes M, Boelee E: Early biting rhythm in the Afro-tropical vector of malaria, Anopheles arabiensis, and challenges for its control in Ethiopia. Med Vet Entomol 2012, 26:103-105.

doi:10.1186/1475-2875-13-356

Cite this article as: Animut et al.: Distribution and utilization of vector control strategies in a malarious village of Jabi Tehnan District, northwestern Ethiopia. Malaria Journal 2014 13:356.

\section{Submit your next manuscript to BioMed Central and take full advantage of:}

- Convenient online submission

- Thorough peer review

- No space constraints or color figure charges

- Immediate publication on acceptance

- Inclusion in PubMed, CAS, Scopus and Google Scholar

- Research which is freely available for redistribution

Submit your manuscript at www.biomedcentral.com/submit
Ciomed Central 